\title{
Is Ionized Oxygen Negatively or Positively Charged More Effective for Carboxyhemoglobin Reduction Compare to Medical Oxygen at Atmospheric Pressure?
}

\author{
S. PEREČINSKÝ ${ }^{1}$, I. KRON ${ }^{2}$, I. ENGLER ${ }^{3}$, L. MURÍNOVÁ ${ }^{1}$, V. DONIČ ${ }^{3}$, M. VARGA $^{1}$, \\ A. MAROSSY ${ }^{3}$, L. LEGÁTH ${ }^{1}$
}

${ }^{1}$ Department of Occupational Medicine and Clinical Toxicology, Faculty of Medicine, P. J. Šafárik University and the L. Pasteur University Hospital, Košice, Slovakia, ${ }^{2}$ Institute of Medical and Clinical Biochemistry and Labmed, Faculty of Medicine, P. J. Šafárik University, Košice, Slovakia, ${ }^{3}$ Department of Human Physiology, Faculty of Medicine, P. J. Šafárik University, Košice, Slovakia

Received August 21, 2014

Accepted March 10, 2015

On-line June 5, 2015

\section{Summary}

Carbon monoxide (CO) reversibly binds to hemoglobin forming carboxyhemoglobin ( $\mathrm{COHb}$ ). $\mathrm{CO}$ competes with $\mathrm{O}_{2}$ for binding place in hemoglobin leading to tissue hypoxia. Already $30 \%$ saturation of $\mathrm{COHb}$ can be deadly. Medical oxygen at atmospheric pressure as a therapy is not enough effective. Therefore hyperbaric oxygen $\mathrm{O}_{2}$ inhalation is recommended. There was a question if partially ionized oxygen can be a better treatment at atmospheric pressure. In present study we evaluated effect of partially ionized oxygen produced by device Oxygen Ion 3000 by Dr. Engler in elimination of $\mathrm{COHb}$ in vitro experiments and in smokers. Diluted blood with different content of $\mathrm{CO}$ was purged with $5 \mathrm{l} / \mathrm{min}$ of either medicinal oxygen $\mathrm{O}_{2}$, negatively ionized $\mathrm{O}_{2}$ or positively ionized $\mathrm{O}_{2}$ for $15 \mathrm{~min}$, then the $\mathrm{COHb}$ content was checked. In vivo study, 15 smokers inhaled of either medicinal oxygen $\mathrm{O}_{2}$ or negatively ionized $\mathrm{O}_{2}$, than we compared $\mathrm{CO}$ levels in expired air before and after inhalation. In both studies we found the highest elimination of $\mathrm{CO}$ when we used negatively ionized $\mathrm{O}_{2}$. These results confirmed the benefit of short inhalation of negatively ionized $\mathrm{O}_{2}$, in frame of Ionized Oxygen Therapy ( $\mathrm{IO}_{2} \mathrm{Th} /$ Engler) which could be used in smokers for decreasing of $\mathrm{COHb}$ in blood.

\section{Key words}

Ionized oxygen $\bullet$ Negatively ionized $\mathrm{O}_{2} \bullet$ Positively ionized $\mathrm{O}_{2} \bullet$ Ionized Oxygen Therapy $\left(\mathrm{IO}_{2} \mathrm{Th} /\right.$ Engler $) \bullet \mathrm{CO} \bullet \mathrm{COHb} \bullet$ Chronic hypoxia • Smokers

\section{Corresponding author}

S. Perečinský, Department of Occupational Medicine and Clinical Toxicology, Faculty of Medicine, Pavol Jozef Safarik University and the L. Pasteur University Hospital, Rastislavova 43, 04910, Košice, Slovakia. Fax: +421-55-615-2699. E-mail: slavomir.perecinsky@upjs.sk

Carbon monoxide (CO) is a colorless, odorless, tasteless gaseous poison formed during imperfect combustion of any fuel containing carbon. It is also found in cigarette smoke. It reversibly binds to hemoglobin forming carboxyhemoglobin ( $\mathrm{COHb})$. Usually this level is less than $1 \%$ saturation, but patients with hemolytic anemia and smokers may have concentrations greater than $5 \%$. Because carbon monoxide binds about 200 times more strongly to hemoglobin $(\mathrm{Hb})$, than oxygen, even low levels of $\mathrm{CO}$ in air can create $\mathrm{COHb}$. $\mathrm{CO}$ competes with $\mathrm{O}_{2}$ for binding place in $\mathrm{Hb}$ leading to tissue hypoxia and death (Mayes 1993, von Burg 1999).

$\mathrm{CO}$ from $\mathrm{Hb}$ can be removed by lungs ventilation, but the half-life for $\mathrm{COHb}$ is $4-5 \mathrm{~h}$ at a normal atmospheric pressure. Already $30 \%$ saturation of $\mathrm{COHb}$ can be deadly therefore there is no time to wait 4-5 $\mathrm{h}$ for $\mathrm{CO}$ removal by respiration. Therefore inhalation of hyperbaric oxygen $\mathrm{O}_{2}$ at 2.5 at is recommended. This can reduce $\mathrm{COHb}$ half-life to $22 \mathrm{~min}$ (Mayes 1993, Weaver et al. 2000, Prockop and Chichkova 2007). 
However, the ideal dose of $\mathrm{O}_{2}$ during such therapy is unknown so far (Gorman et al. 2003). There are still many controversies on using of oxygen in therapy of carbon monoxide intoxication (Raphael et al. 1989, Juurlink et al. 2005). Despite that, the hyperbaric oxygen therapy $\left(\mathrm{HO}_{2} \mathrm{Th}\right)$ represents a golden standard in $\mathrm{CO}$ intoxication today (Prockop and Chichkova 2007). However, usually if any limited numbers of hyperbaric chambers are available in the case of $\mathrm{CO}$ intoxication. The patients need the transport to the facility and the time is crucial. Using of medical oxygen $\mathrm{O}_{2}$ at atmospheric pressure is not effective enough.

On the other side, because of permanent increasing of $\mathrm{COHb}$, smokers are at risk of chronic hypoxia. High level of $\mathrm{COHb}$ is also associated with coagulopathies, dyslipidemia, atherosclerosis and ischemic heart disease. In the case of Raynaud syndrome $\mathrm{O}_{2} \bullet^{-}$induces periphery vasodilatation (Perecinsky et al. 2014). There was a question if partially ionized oxygen $\left(\mathrm{O}_{2} \bullet^{-}\right.$or $\left.\mathrm{O}_{2} \bullet^{+}\right)$can be a better treatment even at atmospheric pressure. Inhalation of $\mathrm{O}_{2}$ enriched partially with $\mathrm{O}_{2} \bullet^{-}$or $\mathrm{O}_{2} \bullet^{+}$ions produced by commercially available medical device Oxygen Ion 3000 was introduced in 1980 by Dr. Engler in Salzburg in frame of Ionized Oxygen Therapy ( $\mathrm{IO}_{2} \mathrm{Th} /$ Engler). In experiment, $\mathrm{O}_{2} \bullet^{-}$improves the oxygenation of tissues, increases the mobility of respiratory cilia. Inhalation of $\mathrm{O}_{2} \bullet^{-}$during bicycle ergometry showed an increased body performance measured in watt $/ \mathrm{kg}$, which was not achieved by medical $\mathrm{O}_{2}$ inhalation (Engler 2004). Presence of $\mathrm{O}_{2}{ }^{-}$in Pico doses increasing trans membrane resting potentials of cells (TMRP), decreasing sludge of erythrocytes, has anti-inflammatory effect (Engler 2004, Engler et al. 2009).

Present pilot study evaluates effect of partially ionized oxygen (Pico doses of $\mathrm{O}_{2} \bullet^{-}$or $\mathrm{O}_{2} \bullet^{+}$) produced by device Oxygen Ion 3000 for elimination of $\mathrm{COHb}$ in vitro experiments and in smokers. According to our knowledge the similar study has not been published yet.

In vitro experiment removal of $\mathrm{CO}$ from $\mathrm{COHb}$ in human blood using ionized forms of oxygen $\left(\mathrm{O}_{2} \bullet^{-}\right.$or $\left.\mathrm{O}_{2} \bullet^{+}\right)$or oxygen $\left(\mathrm{O}_{2}\right)$ without ionization (Study A)

Human heparinized blood provided by the Blood transfusion unit at the University hospital of L. Pasteur in Košice, Slovakia, blood group $0, \mathrm{Rh}+$ was used. Two samples of $400 \mathrm{ml}$ of blood in a 2-liter round-bottom flask was purged either with CO (Tatragas MesserSlovakia, purity $99.9 \%$ ) with the flow rate $51 /$ min during simultaneous shaking $\left(100 \mathrm{~min}^{-1}\right)$ for $15 \mathrm{~min}=100 \%$ $\mathrm{COHb}$ or with medicinal oxygen (Tatragas MesserSlovakia, purity $99.9 \%$ ) under the same conditions $=0 \%$ $\mathrm{COHb}$. The $\mathrm{COHb}$ content in blood was determined according to Dijkhuizen et al. (1977) by UV-VIS Diode array spectrophotometer Multispec-1501 (Shimadzu, Japan). To $2000 \mu \mathrm{l}$ of distilled water (Millipore-Simplicity, France) was added $2 \mu \mathrm{l}$ of blood and vigorously mixed in the $1 \mathrm{~cm}$ quartz cell. The measurements were performed in triplicate within $5 \mathrm{~min}$ from the sample withdrawal to avoid the losses of $\mathrm{CO}$ content on standing (Beutler and West 1984). The COHb content was calculated by an experimentally determined equation $\left(\% \mathrm{COHb}=\left(383.58 * \mathrm{~A}_{562} / \mathrm{A}_{540}\right)-233.33\right)$. $100 \%$ CO saturated blood was diluted with untreated blood to desired concentrations $50 \%, 25 \%, 12.5 \%$, $6.25 \%$, and $3.1 \%$ of the original carbon monoxide concentration, which were checked by the spectrophotometer. Diluted blood with different content of CO (100 $\mathrm{ml}$ in a volume of 1-liter round-bottom flask) was purged with $4 \mathrm{l} / \mathrm{min}$ flow of either medicinal oxygen $\mathrm{O}_{2}$ or partially negatively ionized oxygen $\mathrm{O}_{2} \bullet^{-}$(120000 ions of $\mathrm{O}_{2} \cdot / \mathrm{cm}^{3}$ of $\mathrm{O}_{2}$ ) or partially positively ionized oxygen $\mathrm{O}_{2} \bullet^{+}\left(135000\right.$ ions of $\mathrm{O}_{2} \bullet^{+} / \mathrm{cm}^{3}$ of $\left.\mathrm{O}_{2}\right)$, respectively. For ionization of $\mathrm{O}_{2}$ was used device Oxygen Ion 3000 by Dr. Engler (CS Tronik, Austria). All samples were simultaneously shaking during $15 \mathrm{~min}$ in a fume cupboard and then the $\mathrm{COHb}$ content was checked by spectrophotometer. All experiments were performed at least 3 times at $22{ }^{\circ} \mathrm{C}$ room temperature. The results were evaluated statistically using t-test.

Table 1 shows results of elimination of $\mathrm{CO}$ from blood with different initial $\mathrm{COHb}$ concentrations in percentage (the first column) by using medicinal oxygen $\mathrm{O}_{2}$ and oxygen enriched with $\mathrm{O}_{2} \bullet^{-}$or $\mathrm{O}_{2} \bullet^{+}$ions, respectively.

Table 1. The efficiency (in \%) of various oxygen species in elimination of $\mathrm{CO}$ from $\mathrm{COHb}$ in the heparinized human blood.

\begin{tabular}{cccc}
\hline \% COHb & $\mathbf{O}_{\mathbf{2}}$ & $\mathbf{O}_{\mathbf{2}}{ }^{-}$ & $\mathbf{O}_{\mathbf{2}}{ }^{+}$ \\
\hline 91.2 & -19.6 & -18.2 & -18.6 \\
46.7 & -28.1 & -20.6 & -19.5 \\
$\mathbf{2 4 . 4}$ & $\mathbf{- 2 8 . 3}$ & $\mathbf{- 3 3 . 2}$ & $\mathbf{- 3 1 . 1}$ \\
$\mathbf{1 7 . 6}$ & $\mathbf{- 3 9 . 8}$ & $\mathbf{- 4 3 . 8}$ & $\mathbf{- 3 2 . 2}$ \\
$\mathbf{1 1 . 9}$ & $\mathbf{- 3 0 . 3}$ & $\mathbf{- 3 5 . 3}$ & $\mathbf{- 2 8 . 7}$ \\
$\mathbf{5 . 9}$ & $\mathbf{- 6 9 . 5}$ & $\mathbf{- 8 3 . 1}$ & $\mathbf{- 5 8 . 5}$ \\
\hline
\end{tabular}

$* \mathrm{P}<0.01$. 
The percentage was calculated as a difference (initial \% $\mathrm{COHb}$ - final \% $\mathrm{COHb}$ ) divided by initial \% $\mathrm{COHb}$ and multiplied by 100 . The most effective in elimination of $\mathrm{CO}$ from blood seems to be the negatively ionized oxygen $\mathrm{O}_{2} \bullet^{-} \quad(\mathrm{P}<0.01)$ compare to medical oxygen $\mathrm{O}_{2}$

From the Table 1 is obvious the strongest effect of negatively ionized oxygen $\left(\mathrm{O}_{2}{ }^{-}\right)$on decrease of $\mathrm{COHb}$ levels below $25 \%$ of $\mathrm{COHb}$ (numbers in bold), which is significant $(\mathrm{P}<0.01)$ especially for the level of $5.9 \%$ $\mathrm{COHb}-\mathrm{a}$ typical level of $\mathrm{COHb}$ for smokers (Lawther and Commins 1970, Beutler and West 1984, Kambam et al. 1986, Gabriel da Costa et al. 1998). The effectiveness of partially negatively ionized oxygen $\left(\mathrm{O}_{2} \bullet^{-}\right)$increases with decreasing $\mathrm{COHb}$ level.

Study in vivo represents a group of 15 smoking subjects, inhaled partially negatively ionized oxygen $\left(\mathrm{O}_{2}{ }^{-}\right)$or medical oxygen $\left(\mathrm{O}_{2}\right)$ or room air without ionization, respectively (Study $B$ )

This study was realized in 3 phases during 3 days in the same 15 smoking subjects. Phase 1 therapy with molecular oxygen $\mathrm{O}_{2}$, phase 2 - therapy with partially negatively ionized oxygen $\left(\mathrm{O}_{2} \bullet^{-}\right)$, phase $3-$ control without therapy (not any form of oxygen were used - subjects breathing room air resting at room temperature). For preparation of $\mathrm{O}_{2} \bullet^{-}$the same device Oxygen Ion 3000 (generated 200000 ions of $\mathrm{O}_{2} \bullet^{-}$in $1 \mathrm{~cm}^{3}$ of $\mathrm{O}_{2}$ at a flow $8 \mathrm{l} / \mathrm{min}$ ) was used. The effect of oxygen therapy with ionized $\mathrm{O}_{2}{ }^{-}$or molecular $\mathrm{O}_{2}$ on the $\mathrm{CO}$ level in exhale air was monitored by a $\mathrm{CO}$ meter (GCO 100 Greisinger Electronic, Germany) and expressed in ppm. Determination of CO level in expired air was chosen due to its simplicity, non-invasiveness and low cost. Moreover, the CO level in expired air correlates very well with $\mathrm{COHb}$ level in blood (Wald et al. 1981, Andersson and Moller 2010). The measurement of CO was performed within 1 min after smoking a cigarette by a person. The person was asked to held breath for $20 \mathrm{~s}$ and then slowly to expire into the $\mathrm{CO}$ meter (the first measurement). Subsequently, the subject inhaled molecular $\mathrm{O}_{2}$ or ionized oxygen $\mathrm{O}_{2} \bullet^{-}$during $20 \mathrm{~min}$ (because of the beneficial effects of $\mathrm{O}_{2}{ }^{-}$in vitro study, subjects inhaled only $\mathrm{O}_{2} \bullet^{-}$and never $\mathrm{O}_{2} \bullet^{+}$). Immediately after $20 \mathrm{~min}$ of oxygen forms inhalation the repeated measurement of $\mathrm{CO}$ in exhaled air was performed using the same technique (second measurement).

Statistical analysis was carried out with the programs Arcus QuickStat (Biomedical). The effect of various oxygen species inhalation was evaluated by percentage of CO level after inhalation versus CO level before inhalation. Using analysis of variance and conversion by Tukey-Kramer test were compared differences in the values of exhaled $\mathrm{CO}$ (expressed as percentages) between groups. Difference between the first and second measurement represents the amount of $\mathrm{CO}$ removed from $\mathrm{COHb}$ by the treatment - inhalation of $\mathrm{O}_{2} \bullet^{-}$or $\mathrm{O}_{2}$.

The best elimination of $\mathrm{CO}$ from $\mathrm{COHb}$ in smokers was achieved by inhalation of $\mathrm{O}_{2} \bullet^{-}$. There were no differences in average values of $\mathrm{CO}$ in the first measurement between all groups. However, in the second measurement the highest average $\mathrm{CO}$ value (in ppm) in exhaled air was seen in group with $\mathrm{O}_{2}{ }^{-}$inhalation. There was statistically significant difference in the increase of $\mathrm{CO}$ value in the second measurement between groups with inhalation of $\mathrm{O}_{2} \bullet^{-}$or $\mathrm{O}_{2}$ and control group. Also we observed difference between the inhalation of $\mathrm{O}_{2} \bullet^{-}$and $\mathrm{O}_{2}$ $(\mathrm{P}=0.016)$ (Fig. 1).

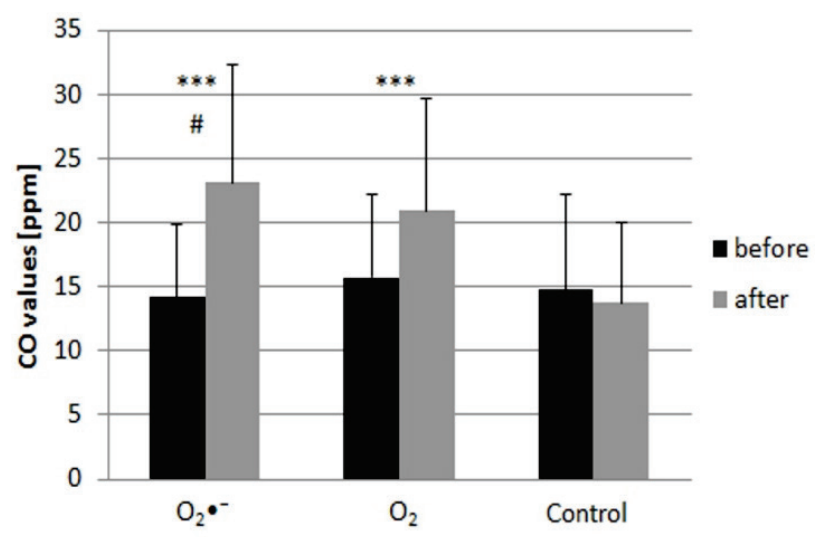

Fig. 1. Differences in expired $\mathrm{CO}$ mean levels (in ppm) before and after inhalation of oxygen $\mathrm{O}_{2}{ }^{-}$or $\mathrm{O}_{2}$ or in control group in 15 smokers. ${ }^{* * *} \mathrm{P}<0.001\left(\mathrm{O}_{2} \bullet^{-}\right.$and $\mathrm{O}_{2}$ vs. control), $\# \mathrm{P}=0.016$ $\left(\mathrm{O}_{2} \bullet^{-}\right.$vs. $\left.\mathrm{O}_{2}\right)$.

In both studies (A and B) partially ionized oxygen $\mathrm{O}_{2} \bullet^{-}$showed the best effect in $\mathrm{CO}$ elimination from binding with $\mathrm{Hb}$. The best effect was seen when $\mathrm{COHb}$ concentration in human blood was less than $25 \%$ and $\mathrm{CO}$ in smokers was under $15 \mathrm{ppm}$ in exhaled air. Inhalation of $\mathrm{O}_{2} \bullet^{-}$in Pico doses may improve oxygenation, mitochondrial functions especially production of ATP as an energetic molecule which is decreasing during hypoxia for example caused by acute or chronic exposition to CO (Engler 2004). This may explain that even very small concentration of $\mathrm{O}_{2} \bullet^{-}$may have a beneficial effect in $\mathrm{COHb}$ elimination in vitro 
experiments or in vivo in smokers. The oxygen radicals $\mathrm{O}_{2}{ }^{-}$in Pico doses in medical oxygen (20 min of inhalation at $8 \mathrm{l} / \mathrm{min}$ flow) has beneficial biological effect as a signal molecule. For example partially negatively ionized oxygen $\left(\mathrm{O}_{2}^{\bullet^{-}}\right)$inhalation was effective in treatment of vibration white finger syndrome in patients (Perecinsky et al. 2014).

Very low doses and short time inhalation of partially ionized oxygen $\left(\mathrm{O}_{2} \bullet^{-}\right)$, according to our opinion cannot increase oxidative stress. It is in accordance with theory of Hormesis (Calabrese and Baldwin 2003).

The similarly as Hormesis theory also Linear-No Treshold Theory of Radiation (Cohen 1999) explain that a small dosis of Radon radiation ( $\mathrm{Rn})$ prevent cancer incidence, but high dose of Rn cause lung cancer. In our experiments with lung fibroblast we find that partially ionized oxygen in Pico doses $\left(\mathrm{O}_{2} \bullet^{-}\right.$or $\left.\mathrm{O}_{2} \bullet^{+}\right)$improve cells damage caused by Rn (Engler et al. 2009).

In the experimental work (Kaplan et al. 2009) free radical-induced oxidative damage and enzyme inhibition was even more pronounced when inhaled oxygen was partially negatively charged $\left(\mathrm{O}_{2} \bullet^{-}\right)$. On the other hand, when inhaled oxygen was partially positively charged $\left(\mathrm{O}_{2} \bullet^{+}\right)$changes were lowered or completely eliminated. In this study a $36 \mathrm{~h}$ of continuous inhalation of ionized oxygen $\mathrm{O}_{2}$ in guinea pigs $(250 \mathrm{~g})$ was used, which was much longer exposition compared with $20 \mathrm{~min}$ in our study with smokers $(70 \mathrm{~kg})$.

It could be helpful to test antioxidant status of the smokers before $\mathrm{O}_{2}{ }^{-}$inhalation, because it can shows how decreasing of $\mathrm{COHb}$ can change oxidative status after inhalation of partially ionized oxygen $\mathrm{O}_{2} \bullet^{-}$.

These results are interesting and may have the important clinical implications. Short $20 \mathrm{~min}$ inhalation of partially ionized oxygen $\left(\mathrm{O}_{2}{ }^{-}\right)$can be used in smokers for decreasing of $\mathrm{COHb}$ in their blood as a prevention of consequences of chronic hypoxia and $\mathrm{CO}$ effect (face skin changes, decreased of physical and psychical performances, arteriosclerosis, ischemic heart disease, etc.). In acute intoxication with $\mathrm{CO}$, inhalation of $\mathrm{O}_{2}{ }^{-}$ could be better option than only medical oxygen inhalation.

\section{Conflict of Interest}

There is no conflict of interest.

\section{Acknowledgements}

The authors would like to acknowledge The Scientific Grant Agency at the Ministry of Education, Slovak Republic and The Agency of the Slovak Ministry of Education for the Structural Funds of the EU, under project ITMS: 26220120067 for the financial support of the research.

\section{References}

ANDERSSON MF, MÖLLER AM: Assessment of carbon monoxide values in smokers: a comparison of carbon monoxide in expired air and carboxyhaemoglobin in arterial blood. Eur J Anaesthesiol 27: 812-818, 2010.

BEUTLER E, WEST C: Simplified determination of carboxyhaemoglobin. Clin Chem 30: 871-874, 1984.

CALABRESE EJ, BALDWIN LA: Hormesis: the dose-response revolution. Annu Rev Pharmacol Toxicol 43: 175-197, 2003.

COHEN BL: Validity of the linear-no treshold theory of radiation, carcinogenesis in the low dose region. In: Radon and Health. DETJEEN P, FALKENBACH A (eds), Peter Lang Verlag, Vienna, 1999, pp 13-37.

DIJKHUIZEN P, BUURSMA A, GERDING AM, VAN KAMPEN EJ, ZIJLSTRA WG: Carboxyhaemoglobin, spectrophotometric determination tested and calibrated using a new reference method for measuring carbon monoxide in blood. Clin Chim Acta 80: 95-104, 1977.

ENGLER I: Handbuch Ionisierter Sauerstoff Therapie im Spiegel der Ganzheitsmedizin. Spurbuch Verlag, D-Baunach, 2004, p. 264.

ENGLER I, ATZMÜLLER C, DONIC V, STEINHÄUSLER F: Reactive oxygen species, especially O2+• in cancer mechanisms. J Exp Ther Oncol 8: 157-165, 2009.

GABRIEL DA COSTA MALHEIROS ACC, PEREIRA BASTOS DE SIQUEIRA ME, ALVAREZ-LEITE EM: Studies on spectrophotometric method for carboxyhaemoglobin determination. Acta Toxicol Argentina 6: 4-7, 1998.

GORMAN D, DREWRY A, HUANG YL, SAMES C: The clinical toxicology of carbon monoxide. Toxicology 187: 25-38, 2003. 
JUURLINK DN, BUCKLEY NA, STANBROOK MB, ISBISTER GK, BENNETT M, MCGUIGAN MA: Hyperbaric oxygen for carbon monoxide poisoning. Cochrane Database Syst Rev 21: CD002041, 2005.

KAMBAM JR, CHEN LH, HYMAN SA: Effect of short-term smoking halt on carboxyhaemoglobin levels and P50 values. Anesthesiol Analgesiol 65: 1186-1188, 1986.

KAPLAN P, TATARKOVA Z, ENGLER I, CALKOVSKA A, MOKRA D, DRGOVA A, KOVALSKA M, LEHOTSKY J, DOBROTA D: Effects of long-term oxygen treatment on alpha-ketoglutarate dehydrogenase activity and oxidative modifications in mitochondria of the guinea pig heart. Eur J Med Res 14 (Suppl 4): 116-120, 2009.

LAWTHER PJ, COMMINS BT: Cigarette smoking and exposure to carbon monoxide. Ann NY Acad Sci 174: 135-174, 1970.

MAYES RW: Measurement of carbon monoxide and cyanide in blood. J Clin Pathol 46: 982-988, 1993.

PERECINSKY S, MURINOVA L, ENGLER I, DONIC V, MURIN P, VARGA M, LEGATH L: Effect of partially ionized medical oxygen, especially $\mathrm{O}_{2} \bullet^{-}$in vibration white finger patients. Int J Environ Res Public Health 11: 5698-5707, 2014.

PROCKOP LD, CHICHKOVA RI: Carbon monoxide intoxication: an updated review. J Neurol Sci 262: 122-130, 2007.

RAPHAEL JC, ELKHARRAT D, JARS-GUINCESTRE MC, CHASTANG C, CHASLES V, VERCKEN JB, GAJDOS P: Trial of normobaric and hyperbaric oxygen for cute carbon monoxide intoxication. Lancet 2: 414-419, 1989.

VON BURG R: Toxicology update. Carbon monoxide. J Appl Toxicol 19: 379-386, 1999.

WALD NJ, IDLE M, BOREHAM J, BAILEY A: Carbon monoxide in breath in relation to smoking and carboxyhaemoglobin levels. Thorax 36: 366-369, 1981.

WEAVER LK, HOWE S, HOPKINS R, CHAN KJ: Carboxyhemoglobin half life in carbon monoxide-poisoned patients treated with $100 \%$ oxygen at atmospheric pressure. Chest 117: 801-808, 2000. 